\title{
Use of oxytocin during Caesarean section at Princess Marina Hospital, Botswana: An audit of clinical practice
}

\begin{tabular}{|c|c|}
\hline \multicolumn{2}{|c|}{$\begin{array}{l}\text { Authors: } \\
\text { Billy M. Tsima }{ }^{1,3} \\
\text { Farai D. Madzimbamuto }{ }^{2} \\
\text { Bob Mash }{ }^{1}\end{array}$} \\
\hline \multicolumn{2}{|c|}{$\begin{array}{l}\text { Affiliations: } \\
{ }^{1} \text { Division of Family } \\
\text { Medicine and Primary Care, } \\
\text { Stellenbosch University, } \\
\text { South Africa }\end{array}$} \\
\hline \multicolumn{2}{|c|}{$\begin{array}{l}{ }^{2} \text { Department of Anaesthesia } \\
\text { and Critical Care, University } \\
\text { of Botswana, Botswana }\end{array}$} \\
\hline \multicolumn{2}{|c|}{$\begin{array}{l}{ }^{3} \text { Department of Family } \\
\text { Medicine, University of } \\
\text { Botswana }\end{array}$} \\
\hline \multicolumn{2}{|c|}{$\begin{array}{l}\text { Correspondence to: } \\
\text { Billy Tsima }\end{array}$} \\
\hline \multicolumn{2}{|c|}{$\begin{array}{l}\text { Email: } \\
\text { btsima@hotmail.com }\end{array}$} \\
\hline \multicolumn{2}{|c|}{$\begin{array}{l}\text { Postal address: } \\
\text { Private Bag 285, Maun, } \\
\text { Botswana }\end{array}$} \\
\hline \multicolumn{2}{|c|}{$\begin{array}{l}\text { Dates: } \\
\text { Received: } 24 \text { Jan. } 2012 \\
\text { Accepted: } 24 \text { Aug. } 2012 \\
\text { Published: } 26 \text { Feb. } 2013\end{array}$} \\
\hline \multicolumn{2}{|c|}{$\begin{array}{l}\text { How to cite this article: } \\
\text { Tsima BM, Madzimbamuto } \\
\text { FD, Mash B. Use of Oxytocin } \\
\text { during Caesarean Section } \\
\text { at Princess Marina Hospital, } \\
\text { Botswana: An audit of clinical } \\
\text { practice. Afr J Prm Health } \\
\text { Care Fam Med. 2013;5(1), } \\
\text { Art. \#418, } 6 \text { pages. } \\
\text { http://dx.doi.org/10.4102/ } \\
\text { phcfm.v5i1.418 }\end{array}$} \\
\hline \multicolumn{2}{|c|}{$\begin{array}{l}\text { Copyright: } \\
\text { (C) 2013. The Authors. } \\
\text { Licensee: AOSIS } \\
\text { OpenJournals. This work } \\
\text { is licensed under the } \\
\text { Creative Commons } \\
\text { Attribution License. }\end{array}$} \\
\hline \multicolumn{2}{|l|}{ Read online: } \\
\hline 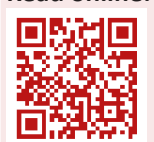 & $\begin{array}{l}\text { Scan this QR } \\
\text { code with your } \\
\text { smart phone or } \\
\text { mobile device } \\
\text { to read online. }\end{array}$ \\
\hline
\end{tabular}

Background: Oxytocin is widely used for the prevention of postpartum haemorrhage. In the setting of Caesarean section (CS), the dosage and mode of administrating oxytocin differs according to different guidelines. Inappropriate oxytocin doses have been identified as contributory to some cases of maternal deaths. The main aim of this study was to audit the current standard of clinical practice with regard to the use of oxytocin during CS at a referral hospital in Botswana.

Methods: A clinical audit of pregnant women having CS and given oxytocin at the time of the operation was conducted over a period of three months. Data included indications for CS, oxytocin dose regimen, prescribing clinician's designation, type of anaesthesia for the CS and estimated blood loss.

Results: A total of 139 case records were included. The commonest dose was 20 IU infusion $(31.7 \%)$. The potentially dangerous regimen of $10 \mathrm{IU}$ intravenous bolus of oxytocin was used in $12.9 \%$ of CS. Further doses were utilized in 57 patients (41\%). The top three indications for CS were fetal distress (36 patients, $24.5 \%$ ), dystocia (32 patients, $21.8 \%$ ) and a previous CS (25 patients, 17.0\%). Estimated blood loss ranged from $50 \mathrm{~mL}-2000 \mathrm{~mL}$

Conclusion: The use of oxytocin during CS in the local setting does not follow recommended practice. This has potentially harmful consequences. Education and guidance through evidence based national guidelines could help alleviate the problem.

L'utilisation d'ocytocine au cours des césariennes à l'hôpital Princess Marina, au Botswana: audit de pratique clinique

Contexte: L'ocytocine est couramment utilisée pour la prévention de l'hémorragie post-partum. Lors d'une césarienne, le dosage et le mode d'administration de l'ocytocine diffèrent d'une directive à l'autre. Des doses inappropriées d'ocytocine ont été identifiées comme contribuant à certains cas de décès maternels. Le principal objectif de cette étude était d'évaluer la norme actuelle de pratique clinique concernant l'utilisation d'ocytocine pendant une césarienne dans un hôpital de référence au Botswana.

Méthodologie: Un audit clinique de femmes enceintes ayant subi une césarienne, et à qui on a administré de l'ocytocine au moment de l'opération, a été réalisé sur une période de trois mois. Les données comprennent les indications de césarienne, la posologie d'ocytocine, la désignation du clinicien prescripteur, le type d'anesthésie pratiqué pour la césarienne et l'estimation de la perte de sang.

Résultats: Un total de 139 cas a été enregistré. La dose la plus courante était une perfusion de 20 UI (31.7\%). La posologie potentiellement dangereuse de 10 UI d'ocytocine par injection intraveineuse a été utilisée dans $12.9 \%$ des césariennes. Des doses supplémentaires ont été utilisées chez 57 patientes (41\%). Les trois premières indications pour la césarienne étaient la souffrance fœetale (36 patients, $24.5 \%$ ), la dystocie (32 patients, $21.8 \%$ ) et une précédente césarienne (25 patients, 17\%). La perte de sang estimée était comprise entre $50 \mathrm{~mL}$ et $2000 \mathrm{~mL}$.

Conclusion: L'utilisation d'ocytocine au cours d'une césarienne dans le contexte local ne suit pas la pratique recommandée. Les conséquences sont potentiellement dommageables. Une éducation et des conseils fournis par des directives nationales avérées pourraient contribuer à atténuer le problème.

\section{Introduction}

The United Nations' Millennium Development Goals (MDG) initiative set specific targets to improve health and development in developing countries. The fifth MDG targets the reduction of maternal mortality by $75 \%$ by the year $2015 .{ }^{1}$ The leading causes of maternal deaths in Africa are haemorrhage (33.9\%), infection (9.7\%) and hypertensive disorders (9.1\%). ${ }^{2}$ In South Africa, obstetric haemorrhage is the third commonest cause of maternal death. ${ }^{3}$ Reports from Botswana highlight 
that in 2009 a total of 86 maternal deaths were recorded in the country. The leading causes were obstetric haemorrhage (15.1\%), unspecified HIV-related disease (12.8\%) and genital tract or pelvic infections $(8.1 \%){ }^{4}$

Botswana has a relatively high maternal mortality rate for a middle income country (330 per 100 000) and Botswana is not on a trajectory to meet the fifth MDG (38 per 100 000) despite $98 \%$ of deliveries occurring in health facilities across the country. ${ }^{1,5}$ Factors that contribute to maternal morbidity and mortality need to be identified and managed in clinical practice to achieve the MDG.

Although oxytocin is widely used in obstetrics, it has been linked with maternal morbidity and mortality. The complications associated with oxytocin include fetal hypoxia, hyperstimulation of the uterus and uterine rupture. ${ }^{6}$ When given as an intravenous bolus, oxytocin causes transient hypotension, reflex tachycardia and an increase in cardiac output in a dose-related manner. $6,7,8,9,10,11$

Apart from being a preventive measure, the use of oxytocin in the perioperative obstetric patient may paradoxically contribute to maternal morbidity and mortality. ${ }^{12}$ The recognition of the potential harm of oxytocin during childbirth has resulted in debate about the appropriate dosing of the drug. Recent research has identified the optimal intravenous dose that balances the risk of side effects with the benefit of preventing post-CS haemorrhage as 3-5 IU after delivery of the baby, as a single prophylactic dose for all cases. ${ }^{13,14,15,16}$

The Royal College of Obstetricians and Gynaecologists and the National Institute for Health and Clinical Excellence recommend $5 \mathrm{IU}$ intravenous bolus to maintain uterine contraction during caesarean delivery, consistent with the licensed dose for the drug. ${ }^{17,18,19}$ However, studies continue to provide evidence for use of even lower doses of oxytocin than those endorsed by current guidelines. ${ }^{12,13,14,15,19}$

Furthermore, there appears to be no consensus regarding the optimal infusion rate of oxytocin needed to prevent haemorrhage at CS. $8,20,21,22$ The World Health Organisation (WHO) recommends infusing $20 \mathrm{IU}$ in one litre of crystalloid giving 60 drops per minute over two hours as prophylaxis against bleeding caused by uterine atony during CS. ${ }^{23}$

A survey of 240 obstetric anaesthetists in the UK revealed that $87 \%$ of the 179 respondents gave $10 \mathrm{IU}$ oxytocin at CS and $50 \%$ of them gave this by rapid bolus. ${ }^{24} \mathrm{~A}$ survey conducted in other countries demonstrated that up to $14 \%$ of clinicians used a 10 IU bolus oxytocin. ${ }^{25}$ The Confidential Enquiry into Maternal Deaths in the UK identified the use of 10 IU intravenously as a cause of death during the resuscitation of a hypovolaemic patient during CS in the period 1997-1999. ${ }^{12,26}$ In South Africa, two maternal deaths have recently been linked to the use of high doses of oxytocin. ${ }^{26}$

\section{Key focus}

The rates of CS are increasing internationally and are accompanied by a relative increase in the use of uterotonic drugs like oxytocin. ${ }^{27,28,29,30}$ Although oxytocin is used routinely, there appears to be variation in its use beyond the recommended approach. ${ }^{24,25,26,31}$ This variation is likely to pose a risk. It may contribute to maternal deaths and therefore remains a cause for concern.

The current standard of practice with regard to the use of oxytocin during CS at Princess Marina Hospital (PMH) has never been assessed. There are no protocols in place to guide prescribers. The aim of this study was to gauge the current standard of practice in the local setting against best practice and establish a baseline for recommending good clinical practice.

\section{Objectives}

Research on the use of oxytocin continues to reveal that historically high doses of more than $5 \mathrm{IU}$ are not necessary for maintaining uterine contraction post-CS as lower doses are as effective. Lower doses offer the advantage of posing less side effects. The main objective of this study is to assess what the standard of practice is with regard to the use of oxytocin during CS in the local setting where medical officers, nurse and specialist anaesthetists, obstetricians and gynaecologists are involved in the use of the drug. This will be established by documenting the doses of oxytocin used during CS at $\mathrm{PMH}$ and the routes of administering these. Furthermore, the study seeks to establish and document the average estimated blood loss (EBL) during CS where oxytocin was prescribed at $\mathrm{PMH}$ and report the relationship of these two variables. The indications for CS where oxytocin was prescribed will be assessed. Additionally, the types of anaesthesia used during CS where oxytocin was also used is assessed. The standard of practice of oxytocin used around the time of CS is compared with international best practice guidelines as outlined above.

\section{Contribution to field}

The dangers of high oxytocin doses were highlighted following a maternal death in the UK in which oxytocin was a possible significant contributory. There has been pressure ever since to reduce the oxytocin dose and provide evidence of efficacy of a lower dose. There is a body of literature on oxytocin guidelines from the WHO and professional bodies, but there is little available on implementation and compliance with the guidelines. This paper attempts to fill this gap.

\section{Ethical consideration}

Ethical approval was obtained from the Health Research Ethics Committee at the University of Stellenbosch and the Research Ethics Committees of the Botswana Ministry of Health and the PMH. A waiver of patient consent was obtained since the study only required examination of routinely maintained medical records. 


\section{Method \\ Study design}

The study design is a clinical audit of current practice involving a case record review of routinely maintained medical records.

\section{Context of the study}

$\mathrm{PMH}$ is one of three major public referral hospitals in Botswana. It is located in the capital city of Gaborone and provides essential obstetric service for a population of over 191000 residents. Additionally, PMH receives referrals from primary and secondary health facilities in the southern part of Botswana, a catchment population of about one million people. In Botswana, the various clinicians directly involved with the use of oxytocin during CS include medical officers, anaesthetic nurses, obstetricians and anaesthetists. A dedicated obstetrics and gynaecology theatre is operational on a 24-hour basis catering for emergency and elective operations. Medical officers (non-specialists) in the department of obstetrics and gynaecology work on a rotational basis to perform CS at the hospital. Anaesthesia is similarly offered by the anaesthetic department's medical officers, anaesthetic nurses and specialists. On average, 128 CS are performed out of a total of 540 monthly deliveries at PMH.

All post-CS mothers are admitted to one ward with an average length of stay of about three days. Case records, including anaesthetic records, are kept in the ward until the patient is discharged.

\section{Selection and sampling of patients}

The study was conducted between 01 March and 31 May 2011. Data were transcribed from case records of all women admitted to the post-natal ward following a CS done at PMH, where oxytocin was used during and after the operation.

\section{Data collection}

We reviewed case notes of all post-CS patients admitted to the ward. These were identified from the admission register kept in the ward and cross-checked with the theatre record. The medication chart, operative notes and anaesthetic record were all reviewed. Only case notes where oxytocin had been prescribed were included.

A structured data collection form was developed to gather information on age, oxytocin dose, route of administration, whether further doses of uterotonics were used, indication for CS, whether the CS was elective or an emergency, type of anaesthesia, estimated blood loss (EBL) and prescriber's designation. The information was transcribed into the data collection form and later into an electronic spreadsheet (MS Excel).

Where there was more than one indication for CS recorded in the case notes, all were noted as separate indications in the results. Dystocia was taken to include cephalopelvic
TABLE 1: Type of anaesthesia in emergency and elective Caesarean section.

\begin{tabular}{lcccccccc}
\hline Anaesthesia & \multicolumn{2}{c}{ Elective $(\boldsymbol{N}=\mathbf{2 4})$} & & \multicolumn{2}{c}{ Emergency $(\boldsymbol{N}=\mathbf{1 1 5})$} & & \multicolumn{2}{c}{ Total $(\boldsymbol{N}=\mathbf{1 3 9})$} \\
\cline { 2 - 3 } & $\boldsymbol{n}$ & $\mathbf{\%}$ & & $\boldsymbol{n}$ & $\mathbf{\%}$ & & $\boldsymbol{n}$ & $\mathbf{\%}$ \\
\hline Spinal & 16 & 11.5 & & 34 & 24.5 & & 50 & 36.0 \\
General & 8 & 5.6 & & 81 & 58.3 & & 89 & 64.0 \\
\hline
\end{tabular}

$N$, Given as total number; $n$, Given as number.

TABLE 2: Indications for Caesarean section $(N=147)$.

\begin{tabular}{lcc}
\hline Indication & $\boldsymbol{n}$ & $\mathbf{\%}$ \\
\hline Fetal distress & 36 & 24.5 \\
Dystocia & 32 & 21.8 \\
Previous CS and/or Myectomy & 25 & 17 \\
Antepartum haemorrhage & 13 & 8.8 \\
Malposition (breech, transverse lie) & 12 & 8.2 \\
Failed induction of labour and/or Postdates & 10 & 6.8 \\
Eclampsia and/or Severe pre-eclampsia & 6 & 4.1 \\
Other (multiple fibroids, twins and/or poor maternal effort) & 4 & 2.7 \\
Cord prolapse & 3 & 2 \\
Bad obstetric history & 2 & 1.4 \\
Medical condition & 2 & 1.4 \\
Ruptured uterus & 1 & 0.7 \\
Intrauterine growth restriction & 1 & 0.7 \\
\hline
\end{tabular}

$N$, Given as total number; $n$, Given as number.

disproportion, delayed first and second stage of labour and failed vacuum extraction.

\section{Data analysis}

Descriptive statistics such as frequencies, means and percentages were used for the analysis of the pooled data. Estimated blood loss and oxytocin dose were compared using regression and Spearman's correlation analysis.

\section{Results}

A total of 139 mothers out of the 145 mothers prescribed oxytocin during CS were included in the study with a mean maternal age of 28.9 years (a range of $16-43$ years). Six mothers were excluded due to insufficient documentation. Out of these operations, $24(17.3 \%)$ were elective and 115 $(82.7 \%)$ were emergency. General anaesthesia was the most popularly used, accounting for $64 \%$, whilst spinal anaesthesia accounted for the other $36 \%$ (Table 1). For emergency CS, general anaesthesia was used in 81 per $115(70.4 \%)$ of mothers compared to 8 per 24 (33.3\%) of elective CS. Use of epidural anaesthesia was not reported.

The top three indications for CS were fetal distress (36 patients, $24.5 \%$ ), dystocia (32 patients, $21.8 \%$ ) and a previous CS (25 patients, 17.0\%) (Table 2). One CS was performed for poor maternal effort - a reason not usually recognized as a standard indication for CS. Where multiple indications were recorded, all were noted as separate indications and the percentage shown is out of all 147 indications. No maternal deaths were recorded during the study.

The indications for CS differed according to whether the CS was an emergency or elective operation (Tables 3 \& Table 4). Percentages are calculated from the total number of indications recorded. 
TABLE 3: Indications for emergency Caesarean section $(N=125)$.

\begin{tabular}{lcc}
\hline Indication & $f$ & $\%$ \\
\hline Fetal distress & 36 & 28.8 \\
Dystocia & 29 & 23.2 \\
Previous Caesarean section in labour & 14 & 11.2 \\
Antepartum haemorrhage & 13 & 10.4 \\
Malposition & 12 & 9.6 \\
Eclampsia & 6 & 4.8 \\
Cord prolapse & 3 & 2.4 \\
Postdates & 3 & 2.4 \\
Failed Induction of labour & 2 & 1.6 \\
Medical condition & 2 & 1.6 \\
Ruptured uterus & 1 & 0.8 \\
Intrauterine growth restriction & 1 & 0.8 \\
Bad obstetric history & 1 & 0.8 \\
Twins & 1 & 0.8 \\
Poor maternal effort & 1 & 0.8 \\
\hline Total & $\mathbf{1 2 5}$ & $\mathbf{1 0 0}$ \\
\hline
\end{tabular}

$N$, Given as total number; $n$, Given as number; $f$, Frequency.

TABLE 4: Indications for elective Caesarean section $(N=24)$

\begin{tabular}{lcc}
\hline Indication & $\boldsymbol{n}$ & $\mathbf{\%}$ \\
\hline Previous Caesarean section & 12 & 50 \\
Dystocia & 6 & 25 \\
Postdates & 5 & 20.8 \\
Bad obstetric history & 1 & 4.2 \\
\hline Total & $\mathbf{2 4}$ & $\mathbf{1 0 0}$
\end{tabular}

$N$, Given as total number; $n$, Given as number.

TABLE 5: Different dose regimens of oxytocin used $(N=139)$.

\begin{tabular}{llcc}
\hline Dose (IU) & Route & $\boldsymbol{n}$ & $\mathbf{\%}$ \\
\hline 5 & IV bolus & 41 & 29.5 \\
10 & IV bolus & 18 & 12.9 \\
15 & IV bolus & 2 & 1.4 \\
20 & IV bolus & 3 & 2.2 \\
10 & IV infusion & 28 & 20.1 \\
15 & IV infusion & 1 & 0.7 \\
20 & IV infusion & 44 & 31.7 \\
30 & IV infusion & 1 & 0.7 \\
40 & IV infusion & 1 & 0.7 \\
\hline
\end{tabular}

$N$, Given as total number; $n$, Given as number.

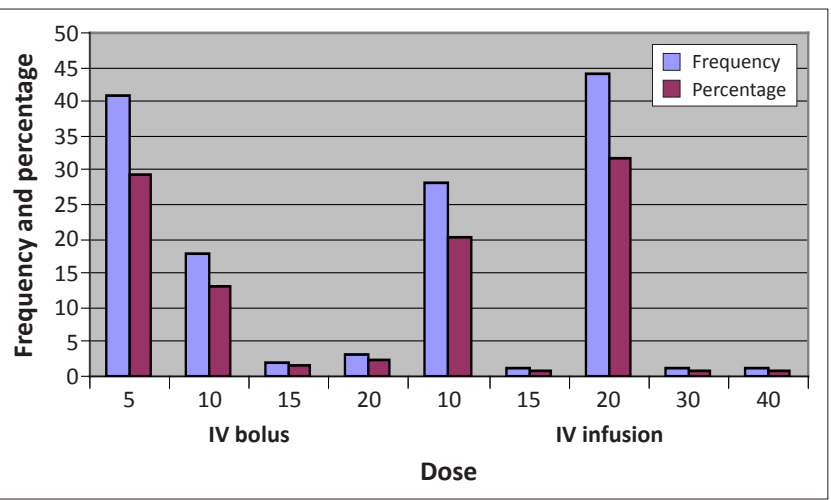

FIGURE 1: Different doses and routes of administration of oxytocin.

Different doses and routes of administration for oxytocin were observed (Table 5 \& Figure 1). The commonest dose used was $20 \mathrm{IU}$ intravenous infusion (31.7\%).

Further doses of uterotonics were utilized in 57 of the mothers (41\%) and this included different doses of oxytocin and syntometrine.
TABLE 6: Dose of oxytocin used and the estimated blood loss.

\begin{tabular}{lcc}
\hline Dose & Mean blood loss $(\mathrm{mL})$ & Blood loss range $(\mathrm{mL})$ \\
\hline 5 IU IV bolus & 382 & $100-1500$ \\
10 IU IV bolus & 346 & $0-900$ \\
10 IU IV infusion & 320 & $100-900$ \\
15 IU IV bolus & 350 & 350 \\
15 IU IV infusion & 100 & $100-200$ \\
20 IU IV bolus & 750 & $300-1200$ \\
20 IU IV Infusion & 493 & $100-2000$ \\
30 IU IV infusion & 500 & $500-1200$ \\
40 IU IV infusion & 500 & 500 \\
\hline
\end{tabular}

TABLE 7: Oxytocin prescription by different categories of prescribers.

\begin{tabular}{|c|c|c|}
\hline Dose & Prescriber & $f$ \\
\hline \multirow[t]{4}{*}{5 IU IV bolus } & Anaesthetic nurse & 7 \\
\hline & Medical officer & 37 \\
\hline & O \& G Specialist & 1 \\
\hline & Anaesthetist & 1 \\
\hline \multirow[t]{4}{*}{10 IU IV bolus } & Anaesthetic nurse & 2 \\
\hline & Medical officer & 16 \\
\hline & O \& G Specialist & 0 \\
\hline & Anaesthetist & 0 \\
\hline \multirow[t]{4}{*}{10 IU Infusion } & Anaesthetic nurse & 0 \\
\hline & Medical officer & 25 \\
\hline & O \& G specialist & 0 \\
\hline & Anaesthetist & 0 \\
\hline \multirow[t]{4}{*}{20 IU IV bolus } & Anaesthetic nurse & 3 \\
\hline & Medical officer & 0 \\
\hline & O \& G specialist & 0 \\
\hline & Anaesthetist & 0 \\
\hline \multirow[t]{4}{*}{30 IU Infusion } & Anaesthetic nurse & 0 \\
\hline & Medical officer & 0 \\
\hline & O \& G specialist & 1 \\
\hline & Anaesthetist & 0 \\
\hline \multirow[t]{4}{*}{40 IU Infusion } & Anaesthetic nurse & 0 \\
\hline & Medical officer & 1 \\
\hline & O \& G specialist & 0 \\
\hline & Anaesthetist & 0 \\
\hline
\end{tabular}

$f$, Frequency.

Estimated blood loss ranged from $50 \mathrm{~mL}-2000 \mathrm{~mL}$. The mean blood loss and the corresponding oxytocin doses prescribed (see Table 6).

Prescribing practices differed widely, with medical officers and anaesthetic nurses accounting for all instances where the $10 \mathrm{IU}$ intravenous bolus was used (Table 7). Anaesthetic nurses accounted for the three times where an intravenous bolus of 20 IU bolus was used.

There was a statistically significant relationship between the oxytocin dosage used and the estimated blood loss $(p=0.03)$, although the strength of the association was low $(r=0.19)$. The oxytocin dose increased with increasing estimated blood loss (Figure 2).

\section{Discussion}

The present study revealed that only $30 \%$ of users adhered to the recommended practice of $5 \mathrm{IU}$ intravenous oxytocin at CS. A total of $31.7 \%$ of participants in the study used an infusion of $20 \mathrm{IU}$ in one litre of a crystalloid solution. As the 


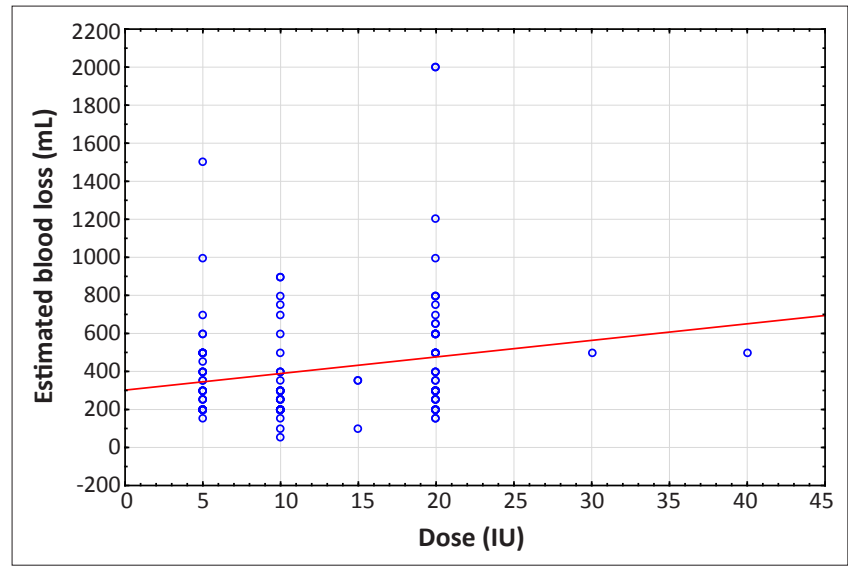

Dose (IU): Estimated blood loss (mL): $r=0.1956, p=0.0257$, Spearman $r=0.19, \mathrm{p}=0.03$.

FIGURE 2: Dose (IU) of oxytocin vs. estimated blood loss $(\mathrm{mL})$ for all regimens.

infusion rates were not recorded, it was difficult to say if the WHO guideline was followed.

The low correlation of dosage and EBL suggests that choice of dosage is only weakly associated with the perception of blood loss and that variation in dose is most likely dependent on other factors. One would have expected a greater correlation between increasing dose of oxytocin and the higher EBL associated with post-partum haemorrhage in instances where an initial dose of oxytocin did not arrest the bleeding. However, this study did not differentiate between whether oxytocin was prescribed for prophylaxis against post-partum haemorrhage, or for its management once it had been diagnosed. Estimation of blood loss at CS is known to vary widely according to a clinician's perception and may have a large subjective element. ${ }^{24}$ Additionally, the skills and experience of the surgeon doing the CS is an important factor in the resulting blood loss from the surgery.

The number of oxytocin receptors expressed in the myometrium increases as pregnancy advances from 12 weeks gestation..$^{32}$ Following continuous and prolonged exposure to oxytocin, there is significant loss in the capacity of the myometrial cells to respond as a result of oxytocin receptor desensitisation. ${ }^{33,34,35}$ It is in view of this physiological fact that there has been recommendations to consider other uterotonics where additional doses of oxytocin prove not to adequately control haemorrhage since these alternatives are not affected by the desensitation..$^{6,26}$

The high proportion of emergency to elective CS noted is likely due to the fact that high risk pregnancies are referred to $\mathrm{PMH}$ as emergencies.

Fetal distress (FD) was the commonest indication overall for CS and emergency CS where oxytocin was used, contributing $25 \%$ and $28.2 \%$ respectively. Although this study looked at a subset of women who were prescribed oxytocin during CS and not all women who had CS, the percentages regarding FD appear high. International studies suggest that rates for FD as an indication for CS were as low as $6 \%-17 \%$ in Ghana and as high as $46 \%$ in the UK for repeated emergency CS. ${ }^{36,37}$
The significant contribution of FD as an indication for CS in our study begs the question of whether this entity is accurately diagnosed, since the diagnosis is made on observation of fetal heart rate on cardiotocograph. Despite the high sensitivity of cardiotocograph in detecting FD, it has a high rate of false positives, as well as inter- and intra-observer variation. ${ }^{38}$

The rates of general anaesthesia used during the study appear higher than in other African countries such as Nigeria, which reported a rate of $47.6 \% .^{39}$ The high uptake of general anaesthesia as opposed to regional anaesthesia in this study potentially increases the risk of anaesthesia-related causes of maternal morbidity and mortality since general anaesthesia is a recognised risk for most direct anaesthetic deaths. ${ }^{40}$

\section{Limitaions and strengths of the study}

The unique setting of $\mathrm{PMH}$ that provides local district hospital type services and regional referral hospital services with a high volume of patients, presents a peculiar advantage in conducting this study. A variety of users were represented in the study with the majority being non-specialists - a situation closer in reality to the staff compliment of primary and district hospitals in Botswana.

The study did not identify specific individuals (but rather groups) who prescribed specific doses and thus potentially harmful practice could not be linked to specific individuals. However, this is useful in not creating a climate of blame - a clear objective of clinical audit.

The study could not distinguish whether oxytocin was primarily given as prophylaxis or treatment nor what the infusion rate was, since this was not stated in the case records from which data was transcribed. This highlights the fact that patient notes were not being adequately recorded. The deficiency in data could have been addressed better in a prospective study.

\section{Practical implications and recommendations}

The effort to improve the current clinical practice with regard to the use of oxytocin during CS in the local setting, could include developing a national protocol for prophylactic use of oxytocin at CS. Junior doctors, anaesthetic nurses and nonspecialist doctors should be targeted for continuing medical education activities that include training on the appropriate use of oxytocin at CS. This should also be addressed in the initial training of these clinicians and that of family physicians as they rotate through the departments of Obstetrics and Anaesthetics at PMH and other centres.

A re-audit of clinical practice after implementation of the protocol and appropriate education should be done.

\section{Conclusions}

The use of oxytocin during CS in the local setting does not generally follow recommended practice and current literature. This has potentially harmful consequences, such as increased maternal morbidity and mortality. Education and 
guidance by national practice guidelines and local protocols could help alleviate the problem. This audit could be used as a baseline for future assessment of clinical practice at PMH and as a stimulus for similar clinical audits in other centres.

\section{Acknowledgements}

The authors wish to thank prof. Martin Kidd (statistical assistance), Prof. Sunanda Ray and dr Luise Parsons for their support in developing this work.

\section{Competing interest}

The authors declare that they have no financial or personal relationship(s) which may have inappropriately influenced them in writing this article.

\section{Authors' contributions}

B.T. (Stellenbosch University) and F.M. (University of Botswana) conceived the idea for the study. B.T. was principle investigator and collected the data. B.M. (Stellenbosch University) contributed to further development of the concept. B.T. wrote the manuscript, whilst F.M. and B.M. provided editorial comments.

\section{References}

1. United Nations Development Group. National MDG reports. [homepage on the Internet]. July 2008 [cited 2011 April 19]. Available from http://www.undg.org/ index.cfm? $\mathrm{P}=87 \& \mathrm{f}=\mathrm{B}$

2. Khan K, Wojdyla D, Say L, et al. WHO analysis of causes of maternal death: a systemic review. Lancet. 2006;367:1066-1074. http://dx.doi.org/10.1016/S01406736(06)68397-9

3. Fawcus $S$, Moodley J. Haemorrhage associated with caesarean section - be aware. S Afr Med J. 2011;101(5):306-309. PMid:21837869

4. Central Statistics Office. Health Statistics [homepage on the internet]. 2011 [cited 2011 July 11]. Available from: http://www.cso.gov.bw

5. Central Statistics Office. Botswana Multiple Indicator Survey. Gaborone: Government Printers; 2001.

6. Langesaeter E, Rosseland L, Stubhaug A. Haemodynamic effects of repeated dose of oxytocin during Caesarean delivery in healthy parturients. $\mathrm{Br} J$ Anaesth. 2009;103(2):260-262. http://dx.doi.org/10.1093/bja/aep137, PMid:19502285

7. Pinder AJ, Dresner C, Calow $G$, et al. Haemodynamic changes caused by oxytocin during caesarean section under spinal anaesthesia. Int J obstet Anaesth. 2002;11:156-159. http://dx.doi.org/10.1054/ijoa.2002.0970, PMid:15321540

8. Thomas JS, Koh S, Cooper G. Haemodynamic effects if oxytocin given as i.v. bolus or in fusion on women undergoing Ceasarean section. BJA. 2007;98:116-119. http://dx.doi.org/10.1093/bja/ael302, PMid:17142825

9. Jonsson $M$, Hanson $U$, Lindell $C$, et al. ST depression at Caesarean section and the relation to oxytocin dose. A randomised control trial. BJOG. 2010;117:76-83. $\mathrm{http} / / / \mathrm{dx}$.doi.org/10.1111/j.1471-0528.2009.02356.x, PMid:19781043

10. Connell JE, Mahomed K. Medical methods for preventing blood loss at Caesarean section (protocol). The Cochrane Database Syst Rev. 2009;1:CD007576.

11. Basson E, Odendaal HJ, Grove D. Oxytocin use in South Africa - a review. S Afr Med J. 2004;94:839-845. PMid:15532761

12. Cooper GM, Lewis G, Neilson J. Confidential enquiries into maternal deaths. 1997-1999. Br J Anaesth. 2002;89:369-372. http://dx.doi.org/10.1093/bja/aef194, PMid:12402712

13. Calvalho JC, Balki M, Kingdom J, Windrim R. Oxytocin requirements at elective Cesarean delivery: a dose-finding study. Obstet Gynecol. 2004;104:1005-1010. http://dx.doi.org/10.1097/01.AOG.0000142709.04450.bd, PMid:15516392

14. Butwick AJ, Coleman L, Cohen SE, et al. Minimum effective bolus dose of oxytocin during elective Caesarean delivery. Br J Anaesth. 2010;104:338-343. http:// dx.doi.org/10.1093/bja/aeq004, PMid:20150347
15. Sartain JB, Barry JJ, Howat PW, et al. Intravenous oxytocin bolus of 2 units is superior to 5 units during elective Caesarean section. Br J Anaesth. 2008;101(6):822-826. http://dx.doi.org/10.1093/bja/aen273, PMid:18845650

16. Balki $M$, Ronayne $M$, Davis $S$, et al. Minimum oxytocin dose requirement after Cesarean delivery for labor arrest. Obstet Gynaecol. 2006;107:45-50. http:// dx.doi.org/10.1097/01.AOG.0000191529.52596.c0, PMid:16394038

17. Royal College of Obstetricians and Gynaecologists. Postpartum haemorrhage, prevention and management (Green-top Guideline 52) [homepage on the internet]. 2009 May 11 [cited 2011 April 20]. Available from http://rcog.org.uk/guidelines

18. National Institute for Health and Clinical Excellence. Caesarean Section [homepage on the internet]. 2009 June 15 [cited 2011 April 19]. Available from http://www. nice.org.uk/nicemedia/live/10940/29334/29334.pdf

19. British Medical Association. Royal Pharmaceutical Society of Great Britain British National Formulary. London; 2003.

20. Dyer RA, Butwick AJ, Carvalho B. Oxytocin for labour and Caesarean delivery: implications for the anaesthesiologist. Curr Opin Anaesth. 2011;24:255-261. http://dx.doi.org/10.1097/ACO.0b013e328345331c, PMid:21415725

21. Sarna MC, Soni AK, Gomez M, Oriol NE. Intravenous oxytocin in patients undergoing elective Caesarean section. Anesth Analg. 1997;84(4):753-756. PMid:9085952

22. George RB, Mackeen D, Chaplin AC, Mcleod L. Up-down determination of the ED90 of oxytocin infusions for the prevention of postpartum uterine atony in parturients undergoing Caesarean delivery. Can J Anaesth. 2010;57(6):578-582. parturients undergoing Caesarean delivery. Can J Anaesth. 2010;57
http://dx.doi.org/10.1007/s12630-010-9297-1, PMid:20238255

23. World Health Organisation. Managing complications in pregnancy and childbirth A guide for midwives and doctors. World Health Organisation; 2007.

24. Wedisinghe L, Macleod M, Murphy DJ. Use of oxytocin to prevent haemorrhage at Ceasarean section - a survey of practice in the United Kingdom. Gynaecol Reprod Biol. 2008;137:27-30. http://dx.doi.org/10.1016/j.ejogrb.2007.04.007, PMid:17544563

25. Sheehan SR, Wedisinghe L, Macleod M, Murphy DJ. Implementation of guidelines on oxytocin use at Caesarean section: A survey of practice in the British Isles. Intern J Gyne \& Obst. 2009;107:336.

26. Dyer RA, van Dyk D, Dresner A. The use of uterotonic drugs during Caesarean section. Inter J Obstet Anaesth. 2010;19:313-319.

27. Betran AP, Merialdi M, Lauer JA, et al. Rates of Caesarean section: analysis of global, regional and national estimates. Paediatr Perinat Epidemiol. 2007;21(2):98-113. http://dx.doi.org/10.1111/j.1365-3016.2007.00786.x, PMid:17302638

28. Althabe F, Sosa C, Belizan JM, et al. Caesarean section rates and maternal and neonatal mortality in low-, medium- and high-income countries: an ecological study. Birth. 2006;33(4):270-271. http://dx.doi.org/10.1111/j.1523-536X.2006.00118.x PMid:17150064

29. Naidoo RP, Moodley J. Rising rates of Caesarean sections: An audit of Caesarean sections in a specialist private practice. SA Fam Pract. 2009;51(3):254-258.

30. Nula M, Thinkhamprop J, Seejorn K, et al. Rising Caesarean delivery rates at a tertiary care centre in Thailand. Inter J Gynaecol Obstet. 2010;110(1):76-77. http://dx.doi.org/10.1016/j.ijgo.2010.03.006, PMid:20394924

31. Bolton TJ, Randall K, Yentis SM. Effects of the confidential enquiries into maternal deaths on the use of syntocinon at Caesarean section in the UK. Anaesth. 2003;58:261-279. http://dx.doi.org/10.1046/j.1365-2044.2003.30435.x

32. Kimura T, Takemura $M$, Nomura $S$, et al. Expression of oxytocin receptors in human pregnant myometrium. Endocrine Journal. 1996;137:780-785. http://dx.doi.org/ 10.1210/en.137.2.780

33. Glimpl G, Fahrenholtz F. The oxytocin receptor system: structure, function and regulation. Physiological Reviews. 2001;81(2):629-683.

34. Arias F. Pharmacology of oxytocin and prostagladins. Clin Obstet Gynecol. 2000;43:455-468. http://dx.doi.org/10.1097/00003081-200009000-00006, PMid:10949750

35. Phaneuf S, Asboth G, Carrasco MP, et al. The desensitation of oxytocin receptors in human myometrial cells is accompanied by down-regulation of oxytocin receptor messenger RNA. Endocrine Journal. 1997;154:7-18. http://dx.doi.org/10.1677/ joe.0.1540007

36. Kwawukume EY. Caesarean section in developing countries. Best Pract Research: Clinical Obstet Gynae. 2001;15(1):165-172. http://dx.doi.org/10.1053/beog.2000.0155, PMid:11359321

37. Wasef WRK. An audit of trial of labour after previous Caesarean section. J Obstet Gynaecol. 2000;20(4):380-381. http://dx.doi.org/10.1080/01443610050112002, PMid:15512590

38. Davane D, Lalor J. Midwives visual interpretation of intrapartum cardiotograph intra- and inter-observer agreement. J Adv Nurs. 2005;52(2):133-141. http:// dx.doi.org/10.1111/j.1365-2648.2005.03575.x, PMid:16164474

39. Okafar UV, Ezegwui HU, Ekwazi K. Trends of different forms of anaesthesia for Caesarean section in South-Eastern Nigeria. J Obstet Gynaecol. 2009;29(5):392-395. http://dx.doi.org/10.1080/01443610902932390, PMid:19603315 Clinical Obstet Gynae. 2001;15(1):127-143. http://dx.doi.org/10.1053/beog.2000.0153, PMid:11359319 